(C) 2009 Plant Management Network.

Accepted for publication 10 February 2009. Published 2 April 2009.

\title{
Evaluation of Sequential Fungicide Spray Programs for Control of Soybean Rust
}

\author{
Edward J. Sikora, Professor, Department of Entomology and Plant \\ Pathology, Dennis P. Delaney, Extension Specialist, Department of \\ Agronomy and Soils, Mary A. Delaney, Research Epidemiologist, \\ Department of Entomology and Plant Pathology, and \\ Kathy S. Lawrence, Associate Professor, Department of Entomology \\ and Plant Pathology, Auburn University, Alabama, 36849-5624; and \\ Malcomb Pegues, Associate Director, Gulf Coast Research and \\ Extension Center, Fairhope, Alabama 36532
}

Corresponding author: Edward J. Sikora. sikorej@auburn.edu

Sikora, E. J., Delaney, D. P., Delaney, M. A., Lawrence, K. S., and Pegues, M. 2009. Evaluation of sequential fungicide spray programs for control of soybean rust. Online. Plant Health Progress doi:10.1094/PHP-2009-0402-01-RS.

\begin{abstract}
Soybean rust (SBR), caused by the fungus Phakopsora pachyrhiza, has been a recurring problem for soybean growers in the southern United States. In some cases, growers in this region have followed a fungicide spray program consisting of two fungicide applications to protect their crop from the disease. Our study was conducted to determine how various sequential fungicide spray programs perform under the relatively high SBR pressure found in Alabama. Results from this study suggest that there are significant differences in the relative effectiveness of a program based on products used and the sequence in which they are applied. Factors such as recent weather conditions, proximity to sources of SBR, cost of available products, and an estimate of a crops yield potential should be considered when choosing a fungicide program.
\end{abstract}

\section{I ntroduction}

Soybean Rust (SBR), caused by the fungus Phakopsora pachyrhiza, has been a recurring problem for soybean growers in the southern United States since it was first detected in $2004(13,17)$. The pathogen has survived each winter on kudzu and other legume hosts in the Gulf Coast States, including Alabama (17). Because the pathogen successfully overwinters on kudzu along the gulf coast in Alabama, soybeans grown in this area are exposed to the disease at a very early stage of crop development (16). To obtain maximum yields, a soybean crop exposed to SBR must be protected with fungicides from bloom through pod fill (4). With this knowledge the majority of growers along the gulf coast of Alabama have adopted a protective program consisting of two fungicide applications initiated soon after the plant transitions into reproductive stages of growth (E. J. Sikora, personal communication). These applications are typically applied at full bloom and then approximately 21 days later depending on the products used and weather conditions. This program provides crop protection when it is most vulnerable to the disease and appears to have prevented significant yield losses to SBR in Alabama (E. J. Sikora, personal communication).

Many fungicides have been shown to be effective in controlling SBR in countries other than the United States $(5,6,7,8,9,10,11,19)$. In the United States, a limited number of trials have focused on evaluating fungicide spray programs versus individual products for SBR $(2,3,12,14,18)$.

Our study was conducted to determine how various sequential fungicide spray programs perform under relatively high SBR pressure found along the gulf coast of Alabama. Results from these trials will provide growers with information on the performance of products and/or product combinations and allow them to make informed decisions on selecting the best management program for SBR. 


\section{Sequential Fungicide Efficacy Trials}

Sequential fungicide spray programs were evaluated at the Gulf Coast Research and Extension Center in Fairhope, AL, in 2006 and 2007. Experiments were planted 1 June 2006 and 7 June 2007. The variety DP 7870RR was used in 2006 and DP 7220RR was used in 2007. The experiments were planted at a rate of six seeds per $1 \mathrm{ft}$ of row using conventional tillage in a Malbis fine sandy loam soil. Plots consisted of four 25 - $\mathrm{ft}$-long rows with a row spacing of $3 \mathrm{ft}$. Plots were arranged in a randomized complete block design with four replications. A 25 -ft alley separated blocks. All plots were maintained throughout the season with herbicide, insecticide, and fertility production practices as recommended by the Alabama Cooperative Extension System (1). The test area was not irrigated. Fungicides that comprised the various spray programs included triazoles [Folicur (tebuconazole), Laredo EC (myclobutanil), and Topguard (flutriafol)] and triazole + strobilurin premixes [Headline SBR (tebuconazole + pyraclostrobin), Quilt 1.67 EC (propiconazole + azoxystrobin), and Stratego EC (propiconazole + trifloxystrobin)]. Spray programs included: Headline SBR followed by (fb) Headline SBR; Stratego EC fb Stratego EC; Quilt 1.67 EC fb Quilt 1.67 EC, Headline SBR fb Folicur EC; Headline SBR fb Laredo EC; Stratego EC fb Folicur EC; Stratego EC fb Laredo EC; Quilt 1.67 EC fb Folicur EC; Quilt 1.67 EC fb Laredo EC; Headline SBR fb Topguard; Stratego EC fb Topguard; and Quilt 1.67 EC fb Topguard.

Fungicide treatments were applied as a foliar spray at full bloom (R2 growth stage) and repeated approximately 21 days later. Sprays were applied in 24 gal of water per acre in 2006, and $18 \mathrm{gal} /$ acre in 2007, using a Lee Spider high clearance sprayer with Turbodrop TDXL 10002 flat fan nozzles (Greenleaf Technologies, Covington, LA) on 15-inch centers at 60 psi. Non-ionic surfactant was included in some fungicide tank mixtures at $0.125 \% \mathrm{v} / \mathrm{v}$. Fungicide applications were made on 28 July and 15 August 2006; and 31 July and 21 August 2007.

SBR was first observed at relatively low levels on a few leaves on scattered plants at the R4-R5 growth stage in the unsprayed control in mid August in both 2006 and 2007. Disease severity was determined periodically by rating 10 leaves from the low-to-mid canopy of the two center rows of each plot on a 0 to 8 scale with: $\mathrm{O}=$ no SBR, $1=$ up to $2.5 \% ; 2=2.5$ to $5 \% ; 3=5$ to $10 \% ; 4=10$ to $15 \%$; $5=15$ to $25 \% ; 6=25$ to $35 \% ; 7=35$ to $67.5 \%$; and $8=67.5$ to $100 \%$. Yield was determined at harvest on 13 November 2006 and 7 November 2007. Data were statistically analyzed using PROC GLM and where significant differences were indicated means were compared with Fisher's LSD $(\mathrm{P}<0.10)$.

\section{Fungicides Control Soybean Rust and I ncrease Yields}

In 2006, all fungicide treatments reduced the severity of SBR compared to the unsprayed control on all rating dates (Table 1). There were no differences in disease severity among fungicide programs on 19 September. On 27 September the Headline SBR fb Headline SBR, Headline SBR fb Folicur, Headline SBR fb Laredo, Headline SBR fb Topguard, Quilt fb Topguard, and Stratego fb Topguard programs had lower SBR severity ratings than Quilt fb Quilt, Quilt fb Folicur, and Quilt fb Laredo programs. On 9 October the Headline SBR fb Headline SBR, Headline SBR fb Folicur, Headline SBR fb Laredo, Headline SBR $\mathrm{fb}$ Topguard, Quilt fb Topguard, and Stratego fb Topguard programs had lower SBR severity ratings than Quilt fb Quilt, Stratego fb Folicur, Quilt fb Folicur, and Quilt fb Laredo programs. All fungicide treatments increased yields compared to the unsprayed control. The Stratego fb Topguard program had a higher yield $(\mathrm{P} \leq \mathrm{0.10})$ compared to the Quilt fb Quilt, Stratego fb Stratego, and Stratego fb Laredo programs. There were no significant differences in yield among the other programs. 
Table 1. Effect of sequential fungicide spray programs on soybean rust severity and soybean yield, Fairhope, AL, 2006.

\begin{tabular}{|c|c|c|c|c|}
\hline \multirow{2}{*}{$\begin{array}{l}\text { Treatment } \\
\text { rate/acre ( } \& \text { application stage })^{\mathrm{x}}\end{array}$} & \multirow{2}{*}{$\begin{array}{c}\text { Yield }^{\mathrm{Y}} \\
\text { (bu/acre) }\end{array}$} & \multicolumn{3}{|c|}{ Severity of soybean rust ${ }^{z}$} \\
\hline & & 19 Sep & 27 Sep & 9 Oct \\
\hline Untreated & $52.3 \mathrm{~d}$ & $3.9 \mathrm{a}$ & $7.4 \mathrm{a}$ & $8.0 \mathrm{a}$ \\
\hline Headline SBR $7.8 \mathrm{fl}$ oz (R2, R5) & $86.0 \mathrm{ab}$ & $0.0 \mathrm{~b}$ & $0.0 \mathrm{~d}$ & 2.4 ef \\
\hline Stratego $10 \mathrm{fl} \mathrm{oz} \mathrm{(R2,} \mathrm{R5)}$ & $65.2 \mathrm{c}$ & $0.1 \mathrm{~b}$ & $0.7 \mathrm{~d}$ & $4.3 \mathrm{~cd}$ \\
\hline Quilt 14 fl oz (R2, R5) & $76.5 \mathrm{bc}$ & $0.1 \mathrm{~b}$ & $0.9 \mathrm{bc}$ & $6.4 \mathrm{~b}$ \\
\hline $\begin{array}{l}\text { Headline SBR } 7.8 \mathrm{fl} \mathrm{oz} \mathrm{(R2)} \\
+ \text { Folicur } 4 \mathrm{fl} \mathrm{oz} \mathrm{(R5)}\end{array}$ & $82.5 \mathrm{ab}$ & $0.0 \mathrm{~b}$ & $0.2 \mathrm{~d}$ & $3.4 \mathrm{de}$ \\
\hline $\begin{array}{l}\text { Headline SBR } 7.8 \mathrm{fl} \mathrm{oz} \mathrm{(R2)} \\
+ \text { Laredo } 7 \mathrm{fl} \mathrm{oz} \mathrm{(R5)}\end{array}$ & $84.5 a b$ & $0.0 \mathrm{~b}$ & $0.2 \mathrm{~d}$ & $1.7 \mathrm{fg}$ \\
\hline $\begin{array}{l}\text { Headline SBR } 7.8 \mathrm{fl} \mathrm{oz} \text { (R2) } \\
+ \text { Topguard } 7 \mathrm{fl} \mathrm{oz} \mathrm{(R5)}\end{array}$ & $89.7 \mathrm{ab}$ & $0.0 \mathrm{~b}$ & $0.2 \mathrm{~d}$ & $0.5 \mathrm{~g}$ \\
\hline $\begin{array}{l}\text { Stratego } 10 \mathrm{fl} \text { oz (R2) } \\
+ \text { Folicur } 4 \mathrm{fl} \mathrm{oz}(\mathrm{R} 5)\end{array}$ & $82.5 a b$ & $0.0 \mathrm{~b}$ & $0.6 \mathrm{bcd}$ & $5.4 \mathrm{bc}$ \\
\hline $\begin{array}{l}\text { Stratego } 10 \mathrm{fl} \mathrm{oz}(\mathrm{R} 2) \\
+ \text { Laredo } 7 \mathrm{fl} \mathrm{oz}(\mathrm{R} 5)\end{array}$ & $75.8 \mathrm{bc}$ & $0.0 \mathrm{~b}$ & $0.4 \mathrm{~cd}$ & $4.5 \mathrm{~cd}$ \\
\hline $\begin{array}{l}\text { Quilt } 14 \text { fl oz (R2) } \\
+ \text { Folicur } 4 \text { fl oz (R5) }\end{array}$ & $80.3 a b$ & $0.2 \mathrm{~b}$ & $1.2 \mathrm{~b}$ & $5.7 \mathrm{bc}$ \\
\hline $\begin{array}{l}\text { Quilt } 14 \mathrm{fl} \text { oz (R2) } \\
+ \text { Laredo } 7 \mathrm{fl} \mathrm{oz} \mathrm{(R5)}\end{array}$ & $77.3 \mathrm{abc}$ & $0.1 \mathrm{~b}$ & $1.0 \mathrm{bc}$ & $6.0 \mathrm{~b}$ \\
\hline $\begin{array}{l}\text { Quilt } 14 \mathrm{fl} \text { oz (R2) } \\
+ \text { Topguard } 7 \mathrm{fl} \mathrm{oz} \mathrm{(R5)}\end{array}$ & $84.1 \mathrm{ab}$ & $0.0 \mathrm{~b}$ & $0.2 \mathrm{~d}$ & $1.7 \mathrm{fg}$ \\
\hline $\begin{array}{l}\text { Stratego } 10 \mathrm{fl} \text { oz (R2) } \\
+ \text { Topguard } 7 \mathrm{fl} \mathrm{oz} \mathrm{(R5)}\end{array}$ & $92.1 \mathrm{a}$ & $0.0 \mathrm{~b}$ & $0.2 \mathrm{~d}$ & $1.5 \mathrm{fg}$ \\
\hline $\operatorname{LSD}^{x}(P \leq 0.10)$ & 12.6 & 0.2 & 0.6 & 1.3 \\
\hline
\end{tabular}

${ }^{x} \mathrm{R} 2$ = flower at node immediately below the uppermost node with a completely unrolled leaf; R5 = beans beginning to develop at one of the four uppermost nodes with a completely unrolled leaf.

$y$ Mean separation in each column was according to analysis of variance and Fisher's protected LSD $(P=0.10)$.

${ }^{z}$ Disease severity $\%: 0=$ no SBR, $1=$ up to $2.5,2=2.5$ to $5,3=5$ to 10 , $4=10$ to $15,5=15$ to $25,6=25$ to $35,7=35$ to 67.5 , and $8=67.5$ to 100 .

In 2007, all fungicide treatments reduced the severity of SBR compared to the unsprayed control on all rating dates (Table 2). There were no differences among fungicide programs on 26 September. On 3 October the Headline SBR fb Headline SBR, Headline SBR fb Folicur, Headline SBR fb Laredo, Headline SBR fb Topguard, Stratego fb Stratego, Stratego fb Folicur, Quilt fb Folicur, Quilt fb Topguard, and Stratego fb Topguard programs had lower SBR severity ratings than Quilt $\mathrm{fb}$ Quilt, Quilt fb Laredo, and Stratego fb Laredo programs. On 20 October the Headline SBR fb Topguard, Quilt fb Topguard, and Stratego fb Topguard programs had lower SBR ratings than all other treatments. Headline SBR fb Headline SBR, Headline SBR fb Folicur, Headline SBR fb Laredo, Stratego fb Folicur, and Quilt fb Folicur programs had lower SBR severity ratings than Stratego fb Stratego, Quilt fb Quilt, Quilt fb Laredo, and Stratego fb Laredo programs. All fungicide treatments increased yields compared to the unsprayed control. The Headline SBR fb Folicur program had a higher yield compared to the Quilt fb Quilt, Stratego fb Stratego, and Stratego fb Laredo programs. There were no significant differences in yield among the other programs. 
Table 2. Effect of sequential fungicide spray programs on soybean rust severity and soybean yield, Fairhope, AL, 2007.

\begin{tabular}{|c|c|c|c|c|}
\hline \multirow{2}{*}{$\begin{array}{l}\text { Treatment } \\
\text { rate/acre }(\& \text { application stage })^{\mathrm{x}}\end{array}$} & \multirow{2}{*}{$\begin{array}{c}\text { Yield }^{\mathrm{Y}} \\
\text { (bu/acre) }\end{array}$} & \multicolumn{3}{|c|}{ Severity of soybean rust ${ }^{z}$} \\
\hline & & 26 Sep & 3 Oct & 20 Oct \\
\hline Untreated & $50.5 \mathrm{c}$ & $3.5 \mathrm{a}$ & $6.0 \mathrm{a}$ & $8.0 \mathrm{a}$ \\
\hline Headline SBR $7.8 \mathrm{fl} \mathrm{oz} \mathrm{(R2,} \mathrm{R5)}$ & $64.1 \mathrm{ab}$ & $0.0 \mathrm{~b}$ & $0.0 \mathrm{c}$ & $2.5 \mathrm{~d}$ \\
\hline Stratego $10 \mathrm{fl} \mathrm{oz} \mathrm{(R2,} \mathrm{R5)}$ & $60.9 \mathrm{~b}$ & $0.1 \mathrm{~b}$ & $0.1 \mathrm{c}$ & $4.3 \mathrm{c}$ \\
\hline Quilt 14 fl oz (R2, R5) & $62.0 \mathrm{bc}$ & $0.3 \mathrm{~b}$ & $1.5 \mathrm{~b}$ & $6.1 \mathrm{~b}$ \\
\hline $\begin{array}{l}\text { Headline SBR } 7.8 \mathrm{fl} \mathrm{oz} \mathrm{(R2)} \\
+ \text { Folicur } 4 \mathrm{fl} \mathrm{oz} \mathrm{(R5)}\end{array}$ & $68.1 \mathrm{a}$ & $0.0 \mathrm{~b}$ & $0.0 \mathrm{c}$ & $2.7 \mathrm{~d}$ \\
\hline $\begin{array}{l}\text { Headline SBR } 7.8 \mathrm{fl} \text { oz (R2) } \\
+ \text { Laredo } 7 \mathrm{fl} \mathrm{oz} \mathrm{(R5)}\end{array}$ & $63.7 \mathrm{ab}$ & $0.0 \mathrm{~b}$ & $0.1 \mathrm{c}$ & $2.4 \mathrm{~d}$ \\
\hline $\begin{array}{l}\text { Headline SBR } 7.8 \mathrm{fl} \mathrm{oz} \text { (R2) } \\
+ \text { Topguard } 7 \mathrm{fl} \mathrm{oz} \mathrm{(R5)}\end{array}$ & $65.6 a b$ & $0.0 \mathrm{~b}$ & $0.0 \mathrm{c}$ & $0.3 \mathrm{e}$ \\
\hline $\begin{array}{l}\text { Stratego } 10 \mathrm{fl} \text { oz (R2) } \\
+ \text { Folicur } 4 \mathrm{fl} \mathrm{oz} \text { (R5) }\end{array}$ & $64.6 \mathrm{ab}$ & $0.1 \mathrm{~b}$ & $0.1 \mathrm{c}$ & $2.6 \mathrm{~d}$ \\
\hline $\begin{array}{l}\text { Stratego } 10 \mathrm{fl} \mathrm{oz}(\mathrm{R} 2) \\
+ \text { Laredo } 7 \mathrm{fl} \mathrm{oz}(\mathrm{R} 5)\end{array}$ & $63.1 \mathrm{~b}$ & $0.0 \mathrm{~b}$ & $1.1 \mathrm{~b}$ & $5.8 \mathrm{~b}$ \\
\hline $\begin{array}{l}\text { Quilt } 14 \text { fl oz (R2) } \\
+ \text { Folicur } 4 \text { fl oz (R5) }\end{array}$ & $64.3 a b$ & $0.0 \mathrm{~b}$ & $0.0 \mathrm{c}$ & $2.6 \mathrm{~d}$ \\
\hline $\begin{array}{l}\text { Quilt } 14 \text { fl oz (R2) } \\
+ \text { Laredo } 7 \mathrm{fl} \mathrm{oz} \mathrm{(R5)}\end{array}$ & $64.3 a b$ & $0.1 \mathrm{~b}$ & $0.9 \mathrm{~b}$ & $5.9 \mathrm{~b}$ \\
\hline $\begin{array}{l}\text { Quilt } 14 \mathrm{fl} \text { oz (R2) } \\
+ \text { Topguard } 7 \mathrm{fl} \mathrm{oz} \mathrm{(R5)}\end{array}$ & $63.5 \mathrm{ab}$ & $0.0 \mathrm{~b}$ & $0.0 \mathrm{c}$ & $0.8 \mathrm{e}$ \\
\hline $\begin{array}{l}\text { Stratego } 10 \mathrm{fl} \text { oz (R2) } \\
+ \text { Topguard } 7 \mathrm{fl} \mathrm{oz} \mathrm{(R5)}\end{array}$ & $63.7 \mathrm{ab}$ & $0.0 \mathrm{~b}$ & $0.0 \mathrm{c}$ & $0.7 \mathrm{e}$ \\
\hline $\operatorname{LSD}^{X}(P=0.10)$ & 4.15 & 0.32 & 0.62 & 1.1 \\
\hline
\end{tabular}

${ }^{x} \mathrm{R} 2$ = flower at node immediately below the uppermost node with a completely unrolled leaf; R5 = beans beginning to develop at one of the four uppermost nodes with a completely unrolled leaf.

$y$ Mean separation in each column was according to analysis of variance and Fisher's protected LSD $(P=0.10)$.

${ }^{\mathrm{z}}$ Disease severity $\%: 0=$ no SBR, $1=$ up to $2.5,2=2.5$ to $5,3=5$ to 10 , $4=10$ to $15,5=15$ to $25,6=25$ to $35,7=35$ to 67.5 , and $8=67.5$ to 100 .

It was clear that the sequence of fungicide applications was important in optimizing control of SBR. All fungicide programs significantly reduced severity of SBR compared to the unsprayed control in both years of our study. Results were similar to other studies conducted in the southeastern United States $(2,3,12,14,18)$ and internationally $(7)$. Based on these results it is apparent that soybean growers have a variety of effective fungicides available to control SBR.

\section{Differences Observed Among Spray Programs}

There were significant differences in control of SBR among the programs tested. Among the strobilurin plus triazole premix programs, sequential sprays of Headline SBR reduced SBR severity in both years of the study compared to Quilt or Stratego. The Headline SBR program also had significantly higher yields than the Stratego program in 2006 but not in 2007. Summarizing fungicide trials conducted in 12 environments in South America and southern Africa, Miles et al. 2007 (7) states that mixtures of a triazole plus strobilurin tended to be more consistent, providing higher yields with less severe soybean rust, lower AUDPC, and less defoliation.

Programs where Headline SBR, Quilt, or Stratego were applied at R2 fb Topguard 21 days later had lower SBR severity ratings in both years compared to programs with Folicur or Laredo. Topguard applied 21 days after R2 controlled SBR for a longer duration than Folicur or Laredo in each of these spray 
programs. Topguard has been shown to be effective against SBR in previous studies $(7,12,15)$. The longer residual of the active ingredient flutriafol in Topguard has also been observed previously (15). This extended residual activity may allow growers to lengthen the period between fungicide applications when using Topguard. In general, activity of triazoles is believed to be 14 to 21 days whereas with Topguard activity against SBR appears to be extended up to 28 days. This characteristic could allow growers the option of a one-application spray program with Topguard or a comparable product when SBR becomes a risk late in the crop's development and no other foliar diseases are prevalent, eliminating the need for a second fungicide application and reducing cost of production significantly.

In 2006, programs with Headline SBR applied at R2 fb either Folicur or Laredo 21 days later reduced SBR severity on the final rating date compared to programs with Quilt or Stratego applied at R2. There were no differences in SBR severity among the Quilt fb Laredo, Stratego fb Laredo, Quilt fb Folicur, or Stratego fb Folicur programs. In 2007, the Headline SBR fb Laredo program again reduced SBR severity compared to the Stratego fb Laredo and Quilt fb Laredo programs. However, there were no differences between the Headline SBR fb Folicur program compared to the Quilt fb Folicur or Stratego fb Folicur programs. Results suggest that Headline SBR applied at R2 is more effective at reducing early season build-up of SBR than Stratego or Quilt. It also suggests that Folicur applied 21 days after R2 can improve the effectiveness of a program compared to Laredo when Quilt or Stratego are applied at R2 in some years.

\section{Economic Analysis}

An economic analysis indicated that all treatments had a positive net return above the direct cost of the fungicides assuming current input costs and the value of soybeans (Table 3). Yield data indicates an average bushel-per-acre yield across treatments of $72.8 \mathrm{bu} /$ acre, a $42 \%$ increase ( $21.4 \mathrm{bu} / \mathrm{acre}$ ) over the control. The value of the additional yield using a current market price of $\$ 12.00 / \mathrm{bu}$ (time of submission) was $\$ 256.75 /$ acre. Using the six commercial materials and the combinations of fungicides, the average estimated cost per acre using the rates in this experiment was $\$ 23.79 /$ acre. Comparing the additional cost to the additional revenue, a $\$ 233.01 /$ acre return in favor of fungicide use was realized. This was equivalent to a 10:1 return on investment. Even using a more conservative market price of $\$ 8.00 / \mathrm{bu}$, the additional revenue was $\$ 171.20$, or a 7:1 return on investment.

\section{Conclusions}

Growers in the south and in other parts of the United States may need to follow a two-fungicide sequential spray program to control SBR in some years. This study suggests that there can be significant differences in the relative effectiveness of programs based on products used and the sequence they are applied. Factors such as recent weather conditions, proximity to sources of SBR, cost of available products, and an estimate of the crop's yield potential all need to be considered when determining which fungicide program to select. 
Table 3. Economic analysis of the sequential fungicide spray programs.

\begin{tabular}{|c|c|c|c|c|c|}
\hline \multirow{2}{*}{$\begin{array}{l}\text { Treatment } \\
\text { rate/acre ( } \& \text { application stage) }\end{array}$} & \multirow{2}{*}{$\begin{array}{l}\text { Average } \\
\text { (bu/acre) }\end{array}$} & \multirow{2}{*}{\begin{tabular}{|c} 
Yield vs \\
untreated
\end{tabular}} & \multirow{2}{*}{$\begin{array}{l}\text { Unit } \\
\text { cost* }\end{array}$} & $\begin{array}{l}\text { Gross } \\
\text { value }\end{array}$ & $\begin{array}{c}\text { Net } \\
\text { value }\end{array}$ \\
\hline & & & & \multicolumn{2}{|c|}{$\$ 12.00 / \mathrm{bu}$} \\
\hline Untreated & 51.4 & - & 0.00 & - & - \\
\hline Headline SBR $7.8 \mathrm{fl}$ oz $(\mathrm{R} 2, \mathrm{R} 5)$ & 75.0 & 23.6 & 34.12 & 382.80 & 249.68 \\
\hline Stratego $10 \mathrm{fl} \mathrm{oz} \mathrm{(R2,} \mathrm{R5)}$ & 63.0 & 11.6 & 27.04 & 139.80 & 112.76 \\
\hline Quilt $14 \mathrm{fl}$ oz (R2, R5) & 69.2 & 17.8 & 31.06 & 214.20 & 183.14 \\
\hline $\begin{array}{l}\text { Headline SBR } 7.8 \mathrm{fl} \text { oz (R2) } \\
+ \text { Folicur } 4 \mathrm{fl} \mathrm{oz} \mathrm{(R5)}\end{array}$ & 76.6 & 25.2 & 21.44 & 303.00 & 281.56 \\
\hline $\begin{array}{l}\text { Headline SBR } 7.8 \mathrm{fl} \mathrm{oz} \mathrm{(R2)} \\
+ \text { Laredo } 7 \mathrm{fl} \mathrm{oz} \mathrm{(R5)}\end{array}$ & 74.1 & 22.7 & 21.98 & 272.40 & 250.42 \\
\hline $\begin{array}{l}\text { Headline SBR } 7.8 \mathrm{fl} \mathrm{oz}(\mathrm{R} 2) \\
+ \text { Topguard } 7 \mathrm{fl} \mathrm{oz} \mathrm{(R5)}\end{array}$ & 77.6 & 26.2 & 26.09 & 315.00 & 288.91 \\
\hline $\begin{array}{l}\text { Stratego } 10 \mathrm{fl} \mathrm{oz}(\mathrm{R} 2) \\
+ \text { Folicur } 4 \mathrm{fl} \mathrm{oz}(\mathrm{R} 5)\end{array}$ & 73.5 & 22.2 & 17.90 & 265.80 & 247.90 \\
\hline $\begin{array}{l}\text { Stratego } 10 \mathrm{fl} \mathrm{oz}(\mathrm{R} 2) \\
+ \text { Laredo } 7 \mathrm{fl} \mathrm{oz} \mathrm{(R5)}\end{array}$ & 69.4 & 18.0 & 18.44 & 216.60 & 198.16 \\
\hline $\begin{array}{l}\text { Quilt } 14 \text { fl oz (R2) } \\
+ \text { Folicur } 4 \text { fl oz (R5) }\end{array}$ & 72.3 & 20.9 & 19.91 & 250.80 & 230.89 \\
\hline $\begin{array}{l}\text { Quilt } 14 \mathrm{fl} \text { oz (R2) } \\
+ \text { Laredo } 7 \mathrm{fl} \mathrm{oz} \mathrm{(R5)}\end{array}$ & 70.8 & 19.4 & 20.45 & 232.80 & 212.35 \\
\hline $\begin{array}{l}\text { Quilt } 14 \mathrm{fl} \mathrm{oz}(\mathrm{R} 2) \\
+ \text { Topguard } 7 \mathrm{fl} \text { oz (R5) }\end{array}$ & 73.8 & 22.4 & 24.55 & 268.80 & 244.25 \\
\hline $\begin{array}{l}\text { Stratego } 10 \mathrm{fl} \mathrm{oz} \mathrm{(R2)} \\
+ \text { Topguard } 7 \mathrm{fl} \mathrm{oz} \mathrm{(R5)}\end{array}$ & 77.9 & 26.5 & 22.54 & 318.00 & 295.46 \\
\hline
\end{tabular}

* Agri-AFC LLC. (Loxley, AL) provided the products prices.

\section{Acknowledgments}

This research was supported by the Alabama Soybean Producers (check-off) and the Southern Soybean Research Program.

\section{Literature Cited}

1. Everest, J., Sikora, E. J., and Smith, R. 2007. Insect and disease control. Soybean IPM Spray Guide. Coop. Ext. Pub. No. ANR-500A, Auburn Univ., Auburn, AL.

2. Kemerait, R. C., and Sconyers, L. E. 2007. Evaluation of fungicides for control of Asian soybean rust in Moultrie (Trial 1 SSDW Study), Georgia, 2006. Online. Plant Disease Management Reports. Report 1:FCo81. doi:10.1094/PDMRo1. American Phytopathological Society, St. Paul, MN.

3. Kemerait, R. C., Sconyers, L. E., and Jost, P. H. 2007. Evaluation of fungicides for control of Asian soybean rust in Tifton (RDC) Trial), Georgia, 2006. Online. Plant Disease Management Reports. Report 1:FCo83. doi:10.1094/PDMR01. American Phytopathological Society, St. Paul, MN.

4. Miles, M. R., Frederick, R. D., and Hartman, G. L. 2003. Soybean rust: Is the U.S. soybean crop at risk? Online. APSnet Feature, American Phytopathological Society, St. Paul, MN.

5. Miles, M. R., Hartman, G. L., Levy, C., and Morel, W. 2003. Current status of soybean rust control by fungicides. Pesticide Outlook 14:197-200.

6. Miles, M. R., Levy, C., and Hartman, G. L. 2004. Summary of the USDA fungicide efficacy trials to control soybean rust in Zimbabwe 2003-2004. Online. USDA National Information System for the Regional IPM Centers. USDA, Washington, DC.

7. Miles, M. R., Levy, C., Morel, W., Mueller, T., Steinlage, T., Van Rij, N., Frederick, R. D., and Hartman, G. L. 2007. International fungicide efficacy trials for the management of soybean rust. Plant Dis. 91:1450-1458. 
8. Miles, M. R., Morel, W., and Hartman, G. L. 2003. Summary of the USDA fungicide efficacy trials to control soybean rust in Paraguay 2002-2003. Online. USDA National Information System for the Regional IPM Centers. USDA, Washington, DC.

9. Miles, M. R., Morel, W., Steinlage, T. A., and Hartman, G. L. 2004. Summary of the USDA fungicide efficacy trials to control soybean rust in Paraguay 2003-2004. Online. USDA National Information System for the Regional IPM Centers. USDA, Washington, DC.

10. Mueller, T. A., Miles, M. R., Hartman, G. L., and Levy, C. 2007. Evaluations of fungicides and fungicide timing for the control of soybean rust in Zimbabwe, 2005-2006. Online. Plant Disease Management Reports. Report 1FC103. doi:10.1094/PDMRo1. American Phytopathological Society, St. Paul, MN.

11. Mueller, T. A., Miles, M. R., Hartman, G. L., and Morel, W. 2007. Evaluations of fungicides and fungicide timing for the control of soybean rust in Pirapo, Paraguay, 2005-2006. Online. Plant Disease Management Reports. Report 1FC063. doi:10.1094/PDMRo1. American Phytopathological Society, St. Paul, $\mathrm{MN}$.

12. Mueller, T. A., Miles, M. R., Hartman, G. L., O’Brien G. K., Marois, J. J., and Wright, D. L. 2007. Evaluations of fungicides and fungicide timing for the control of soybean rust in northwest Florida, 2006. Online. Plant Disease Management Reports. Report 2:FCo86. doi:10.1094/PDMRo1. American Phytopathological Society, St. Paul, MN.

13. Schneider, R. W., Hollier, C. A., Whitman, H. H., Palm, M. E., McKemy, J. M., Hernandez, J. R., Levy, L., and Devries-Paterson, R. 2005. First report of soybean rust caused by Phakopsora pachyrhiza in the Continental United States. Plant Dis. 89:774.

14. Sconyers, L. E., Kemerait, R. C., Brock, J., Phillips, D. V., Jost, P. H., Sikora, E. J., Gutierrez-Estrada, A., Mueller, J. D., Marois, J. J., Wright, D. L., and Harmon, C. L. 2006. Asian soybean rust development in 2005: A perspective from the southeastern United States. Online. APSnet Feature, American Phytopathological Society, St. Paul, MN.

15. Sikora, E. J., Delaney, D. P., Delaney, M. A., Lawrence, K. S., and Pegues, M. 2008. Evaluation of Topguard for control of Asian soybean rust in Alabama. Phytopathology 98:146.

16. Sikora, E. J., Delaney, D., Delaney, M., and Mullen, J. 2007. Asian soybean rust in Alabama. Coop. Ext. Pub. No. ANR-1310, Auburn Univ., Auburn, AL.

17. Sikora, E., and Hershman, D. 2008. Soybean rust in review: 2004-2007. Pages 2028 in: Using Foliar Fungicides to Manage Soybean Rust. A. E. Dorrance, M. A. Draper, and D. E. Hershman, eds. Bull. SR-2008., NC-504 Land Grant Universities Cooperating.

18. Sikora, E. J., Lawrence, K. S., Gutierrez-Estrada, A., Delaney, D. P., and Pegues, M. 2006. Evaluation of fungicide spray programs for Asian soybean rust in Alabama 2005. Online. Fungicide and Nematicide Tests. Report 61:FCo32. doi:10.1094/FN61. American Phytopathological Society, St. Paul, MN.

19. Sinclair, J. B., and Hartman, G. L. 1995. Management of soybean rust. Pages 6-11 in: Soybean Rust Workshop. J. B. Sinclair and G. L. Hartman, eds. Publ. No. 1, Nat'l Soybean Res. Lab., Coll. of Ag., Consumer and Env. Sci., Univ. of Illinois, Urbana, IL. 